\title{
Antioxidant potential of two Apiaceae plant extracts: A comparative study focused on the phenolic composition
}

\author{
Natália Martins $^{\mathrm{a}, \mathrm{b}}$, Lillian Barros ${ }^{\mathrm{a}, *}$, Celestino Santos-Buelga $^{\mathrm{c}}$, Isabel C.F.R. Ferreira ${ }^{\mathrm{a}, *}$ \\ a Mountain Research Centre (CIMO), ESA, Polytechnic Institute of Bragança, Campus de Santa Apolónia, Apartado 1172, 5301 -855 Bragança, Portugal \\ ${ }^{\mathrm{b}}$ CEB, Centre of Biological Engineering, LIBRO-Laboratório de Investigação em Biofilmes Rosário Oliveira, University of Minho, 4710-057 Braga, Portugal \\ ' GIP-USAL, Faculty of Pharmacy, University of Salamanca, Campus Miguel de Unamuno, 37007 Salamanca, Spain
}

\section{A R T I C L E I N F O}

\section{Article history:}

Received 13 August 2015

Received in revised form 7 October 2015

Accepted 6 November 2015

Available online 19 November 2015

\section{Keywords:}

Coriandrum sativum $\mathrm{L}$.

Pimpinella anisum $\mathrm{L}$.

Apiaceae

Hydromethanolic extract

Phenolic compounds

Antioxidant activity

\begin{abstract}
A B S T R A C T
The present study aimed to characterize the extracts prepared from Pimpinella anisum L. (anise) and Coriandrum sativum L. (coriander) (Apiaceae plants) seeds in terms of phenolic composition, and to correlate the obtained profiles with the antioxidant activity. Anise gave the highest abundance in phenolic compounds ( $42.09 \pm 0.11 \mathrm{mg} / \mathrm{g}$ extract), mainly flavonoids $(28.08 \pm 0.17 \mathrm{mg} / \mathrm{g}$ extract) and phenolic acids $(14.01 \pm 0.06 \mathrm{mg} / \mathrm{g}$ extract), and also the highest antioxidant potential, measured by the ability to inhibit lipid peroxidation and $\beta$-carotene bleaching, the reducing power and the free radical scavenging activity. Apigenin and luteolin derivatives, as also caffeoylquinic acid derivatives seem to be directly related with the higher in vitro antioxidant potential of the anise extract. In contrast, the lower antioxidant potential of coriander seems to be due to its lower abundance in phenolic compounds $(2.24 \pm 0.01 \mathrm{mg} / \mathrm{g}$ extract). Further studies are necessary to evaluate the in vivo antioxidant potential of the tested extracts, but the in vitro experiments already performed highlight them as potential health promoters.
\end{abstract}

(C) 2015 Elsevier B.V. All rights reserved.

\section{Introduction}

Botanical preparations are widely used for multiple purposes (Halberstein, 2005; Petrovska, 2012). Commonly used by primitive societies due to its psychotherapeutic, organoleptic, preservative, mystic and mainly medicinal properties, currently, several studies have described the healing potential of different plant extracts and phytochemicals (Jachak and Saklani, 2007; Nasri et al., 2014; Rubió et al., 2013).

Coriandrum sativum L. (coriander) and Pimpinella anisum L. (anise) are two plant species that belong to the Apiaceae family, which are widely used for their medicinal and culinary properties, but also cosmetic and other industrial applications. Nebulized extracts, infusions, essential oils and other preparations, obtained from coriander fruits/seeds, are frequently used as digestive, carminative, antispasmodic, hypoglycemic, hypolipidemic, diuretic, anti-inflammatory and antimicrobial agents (Dhanapakiam et al., 2008; Nadeem et al., 2013; Pathak et al., 2011). Otherwise, fruits/seeds of anise are commonly recommended as antioxidant, antiseptic, antimicrobial, aperitif, digestive, antispasmodic (in respiratory and gastrointestinal tracts), expectorant, galactogogue,

\footnotetext{
* Corresponding authors. Fax: +351273 325405.

E-mail addresses: lillian@ipb.pt (L. Barros), iferreira@ipb.pt (I.C.F.R. Ferreira).
}

estrogenic, anti-inflammatory and diuretic agents, being these benefits mainly associated with the essential oil (Albertpuleo, 1980; Boskabady and Ramazani-Assari, 2001; Shojaii and Fard, 2012).

Previous studies have reported the antioxidant properties of coriander acetone, aqueous, dichloromethane, ethanol, ether, ethyl acetate, methanol, hexane or hydromethanolic, extracts prepared from fruits/seeds, leaves, shoots, stems, roots or from the whole plant (Dias et al., 2011; de Almeida Melo et al., 2003; Sreelatha and Inbavalli, 2012; Sulaiman et al., 2011; Wangensteen et al., 2004), as also of its essential oils (Neffati et al., 2011; Prakash et al., 2012). However, only a few describe the antioxidant activity of anise extracts, namely derived from the whole plant (Albayrak et al., 2012), seeds (Al-Ismail and Aburjai, 2004; Gülçın et al., 2003) and roots (Andarwulan and Shetty, 1999), as also of its essential oil (Dawidar et al., 2008; Kačániová et al., 2014; Kiralan et al., 2012; Topal et al., 2008).

Increasing evidences have shown that phenolic compounds from plant origin significantly determine its antioxidant potential, being promoters of wellbeing and life expectancy of individuals (Ergin et al., 2013; Fernandez-Panchon et al., 2008; Li et al., 2014). Regarding coriander, the determination and quantification of different classes of phenolic compounds, was previously described for the whole plant (Ramkissoon et al., 2013; Sulaiman et al., 2011), vegetative parts (Barros et al., 2012), leaves and stems (Sreelatha and Inbavalli, 2012; Tang et al., 2013), leaves and seeds 
(Wangensteen et al., 2004), fruits (Barros et al., 2012; Kunzemann and Herrmann, 1977; Msaada et al., 2013; Neffati et al., 2011), roots (Tang et al., 2013), and also leaves and shoots (de Almeida Melo et al., 2005). Nonetheless, a few reports describe the phenolic profile of anise, namely in the seeds (Marques and Farah, 2009), fruits, leaves (Kunzemann and Herrmann, 1977), roots (Andarwulan and Shetty, 1999, 2000), and whole plant (Albayrak et al., 2012).

Despite the existence of all the mentioned studies, the majority failed on detailed phenolic characterization. Therefore, the aim of the present study was to characterize coriander and anise seeds in terms of phenolic compounds, correlating these phytochemicals with the antioxidant activity of the plants' extracts.

\section{Materials and methods}

\subsection{Samples}

Coriandrum sativum L. (coriander) and Pimpinella anisum L. (anise) seeds, previously dried and collected in July-August 2012, were supplied by Soria Natural (Garray-Soria, Spain). Both samples were clean products, with monitored parameters of pesticides, herbicides, heavy metals and radioactivity.

\subsection{Standards and reagents}

Methanol was of analytical grade purity and supplied by Pronalab (Lisbon, Portugal). 2,2-Diphenyl-1-picrylhydrazyl (DPPH) was obtained from Alfa Aesar (Ward Hill, MA, USA). HPLC-grade acetonitrile was obtained from Merck KgaA (Darmstadt, Germany). Formic and acetic acids were purchased from Prolabo (VWR International, France). Phenolic standards (apigenin 7-O-glucoside, apigenin-6-C-glucoside, caffeic acid, chlorogenic acid, $p$-coumaric acid, ferulic acid, hesperetin, quercetin-3-O-rutinoside, luteolin-7$O$-glicuside and luteolin-6-C-glucoside) were from Extrasynthese (Genay, France). Trolox (6-hydroxy-2,5,7,8-tetramethylchroman2 -carboxylic acid), TBA (thiobarbituric acid) and $\beta$-carotene were purchased from Sigma Chemical Co. (St. Louis, MO, USA). Water was treated in a Milli-Q water purification system (TGI Pure Water Systems, Greenville, SC, USA).

\subsection{Preparation of the hydromethanolic extracts}

Anise and coriander hydromethanolic extracts preparation was performed through a maceration of each plant material $(1 \mathrm{~g})$ with $30 \mathrm{~mL}$ of methanol: water $(80: 20, \mathrm{v} / \mathrm{v})$ at $25^{\circ} \mathrm{C}$ and $150 \mathrm{rpm}$, during $1 \mathrm{~h}$. Then, both mixtures were filtered through Whatman No. 4 paper and the residue of each plant was once again extracted with one additional portion $(30 \mathrm{~mL})$ of the hydromethanolic mixture. The extracts of each plant were concentrated at $35^{\circ} \mathrm{C}$ under reduced pressure (rotary evaporator Büchi R-210, Flawil, Switzerland) and then lyophilized (FreeZone 4.5, Labconco, Kansas City, MO, USA).

The lyophilized extracts of both plants were re-dissolved in water to obtain two stock solutions $(20 \mathrm{mg} / \mathrm{mL})$, from which serial dilutions were made in order to determine the antioxidant potential.

\subsection{Analysis of phenolic compounds}

The extracts at a concentration of $5 \mathrm{mg} / \mathrm{mL}$, were analysed using a Hewlett-Packard 1100 chromatograph (Hewlett-Packard 1100, Agilent Technologies, Santa Clara, CA, US) with a quaternary pump and a diode array detector (DAD) coupled to an HP Chem Station (rev. A.05.04) data-processing station. A Waters Spherisorb S3 ODS$2 \mathrm{C}_{18},(3 \mu \mathrm{m}, 4.6 \mathrm{~mm} \times 150 \mathrm{~mm})$ column thermostatted at $35^{\circ} \mathrm{C}$ was used and injection volume of $100 \mu \mathrm{L}$. The solvents used were: (A) $0.1 \%$ formic acid in water, (B) acetonitrile. The elution gradient established was isocratic 15\% B for $5 \mathrm{~min}, 15-20 \%$ B over $5 \mathrm{~min}$, $20-25 \%$ B over $10 \mathrm{~min}, 25-35 \%$ B over $10 \mathrm{~min}, 35-50 \%$ B for $10 \mathrm{~min}$, and re-equilibration of the column, using a flow rate of $0.5 \mathrm{~mL} / \mathrm{min}$. Double online detection was carried out in the DAD using 280 and $370 \mathrm{~nm}$ as preferred wavelengths and in a mass spectrometer (MS) connected to HPLC system via the DAD cell outlet. MS detection was performed in an API 3200 Qtrap (Applied Biosystems, Darmstadt, Germany) equipped with an ESI source and a triple quadrupole-ion trap mass analyzer that was controlled by the Analyst 5.1 software. Zero grade air served as the nebulizer gas ( $30 \mathrm{psi})$ and turbo gas for solvent drying $\left(400^{\circ} \mathrm{C}, 40 \mathrm{psi}\right)$. Nitrogen served as the curtain (20 psi) and collision gas (medium). The quadrupols were set at unit resolution. The ion spray voltage was set at $-4500 \mathrm{~V}$ in the negative mode. The MS detector was programmed for recording in two consecutive modes: Enhanced MS (EMS) and enhanced product ion (EPI) analysis. EMS was employed to show full scan spectra, so as to obtain an overview of all of the ions in sample. Settings used were: declustering potential (DP) $-450 \mathrm{~V}$, entrance potential (EP) $-6 \mathrm{~V}$, collision energy $(\mathrm{CE})-10 \mathrm{~V}$. EPI mode was performed in order to obtain the fragmentation pattern of the parent ion(s) in the previous scan using the following parameters: DP $-50 \mathrm{~V}, \mathrm{EP}-6 \mathrm{~V}, \mathrm{CE}$ $-25 \mathrm{~V}$, and collision energy spread (CES) $0 \mathrm{~V}$. Spectra were recorded in negative ion mode between $\mathrm{m} / \mathrm{z} 100$ and 1000 .

The phenolic compounds were identified by comparing their retention time, UV-vis and mass spectra with those obtained from standard compounds, when available. Otherwise, compounds were tentatively identified comparing the obtained information with available data reported in the literature. For quantitative analysis, a calibration curve for each available phenolic standard was constructed based on the UV signal: apigenin-6-C-glucoside $\left(y=179.52 x+116.83 ; R^{2}=0.999\right)$; caffeic acid $(y=359 x+488.4$; $\left.R^{2}=0.997\right) ; \quad$ chlorogenic acid $\left(y=304.25 x-248.06 ; \quad R^{2}=1\right)$; $p$-coumaric acid $\left(y=706.09 x+1228 ; R^{2}=0.999\right)$; ferulic acid $\left(y=525.36 x+233.82 ; R^{2}=0.999\right)$; hesperitin $(y=792.22 x-76.883$; $\left.R^{2}=0.999\right) ; \quad$ luteolin-7-O-glucoside $\left(y=334.2 x-261.39 ; R^{2}=1\right)$; luteolin-6-C-glucoside $\left(y=423.95 x+91.125 ; R^{2}=1\right)$ and quercetin3 -O-rutinoside $\left(y=280.87 x+373.73 ; R^{2}=0.998\right)$. For the identified phenolic compounds for which a commercial standard was not available, the quantification was performed through the calibration curve of other compound from the same phenolic group. The results were expressed in $\mathrm{mg}$ per $\mathrm{g}$ of dried extract.

\subsection{Evaluation of antioxidant activity}

The antioxidant activity of both plant extracts was evaluated using four different in vitro assays: scavenging effects on DPPH (2,2diphenyl-1-picrylhydrazyl) radicals, reducing power (measured by ferricyanide Prussian blue assay), inhibitions of $\beta$-carotene bleaching and lipid peroxidation in brain cell homogenates by TBARS (thiobarbituric acid reactive substances) assay, as previously described (Martins et al., 2015).

Briefly, the DPPH radical-scavenging activity was evaluated by using an ELX800 microplate Reader (Bio-Tek Instruments, Inc; Winooski, VT, USA). The percentage of DPPH discolouration was calculated using the formula: $\left[\left(A_{D P P H}-A_{S}\right) / A_{D P P H}\right] \times 100$, where $A_{S}$ is the absorbance of the solution containing the sample at $515 \mathrm{~nm}$, and $A_{D P P H}$ is the absorbance of the DPPH solution. The reducing power was accessed through the capacity to convert $\mathrm{Fe}^{3+}$ into $\mathrm{Fe}^{2+}$, measuring the absorbance at $690 \mathrm{~nm}$ in the microplate Reader mentioned above. The inhibition of $\beta$-carotene bleaching was determined using the $\beta$-carotene/linoleate assay; the neutralization of linoleate free radicals avoids $\beta$-carotene bleaching, which is measured by the formula: $\beta$-carotene absorbance after $2 \mathrm{~h}$ of assay/initial absorbance) $\times 100$. Finally, the inhibition of lipid peroxidation was achieved using porcine brain homogenates and evaluating the decrease in thiobarbituric acid reactive substances 
Table 1

Retention time (Rt), wavelengths of maximum absorption in the visible region $\left(\lambda_{\max }\right)$, mass spectral data, identification and quantification of phenolic compounds in anise seeds (mean \pm SD).

\begin{tabular}{|c|c|c|c|c|c|c|c|c|}
\hline \multirow[t]{2}{*}{ Compound } & \multirow[t]{2}{*}{$\operatorname{Rt}(\min )$} & \multirow[t]{2}{*}{$\lambda_{\max }(\mathrm{nm})$} & \multirow{2}{*}{$\begin{array}{l}\text { Molecular } \\
\text { ion }[\mathrm{M}-\mathrm{H}]^{-} \\
(\mathrm{m} / \mathrm{z})\end{array}$} & \multirow[t]{2}{*}{$\operatorname{MS}^{2}(m / z)$} & \multirow[t]{2}{*}{ Tentative identification } & \multicolumn{3}{|l|}{ Quantification } \\
\hline & & & & & & (mg/g extract) & Standards used & Wavelength \\
\hline 1 & 5.1 & 326 & 353 & 191(100), 179(86), 161(7), 135(25) & 3-O-Caffeoylquinic acid & $2.31 \pm 0.03$ & Chlorogenic acid & $280 \mathrm{~nm}$ \\
\hline 2 & 6.0 & 310 & 409 & $201(100), 163(60), 119(60)$ & $p$-Coumaric acid derivative & $0.64 \pm 0.01$ & p-coumaric acid & $280 \mathrm{~nm}$ \\
\hline 3 & 7.1 & 324 & 353 & $\begin{array}{l}\text { 191(67), 179(86), 173(100), 161(10), } \\
\text { 135(33) }\end{array}$ & 4-O-Caffeoylquinic acid & $2.38 \pm 0.01$ & Chlorogenic acid & $280 \mathrm{~nm}$ \\
\hline 4 & 7.8 & 326 & 353 & 191(100), 179(85), 161(22), 135(28) & 5-O-Caffeoylquinic acid & $4.01 \pm 0.02$ & Chlorogenic acid & $280 \mathrm{~nm}$ \\
\hline 5 & 14.0 & 350 & 609 & $\begin{array}{l}489(23), 447(3), 429(14), 357(3) \\
327(5), 339(3), 309(9), 298(6)\end{array}$ & Luteolin 2"-O-hexosyl-6-C-hexoside & $0.27 \pm 0.01$ & $\begin{array}{l}\text { Luteolin-6-C- } \\
\text { glucoside }\end{array}$ & $370 \mathrm{~nm}$ \\
\hline 6 & 14.5 & 346 & 579 & $\begin{array}{l}\text { 459(23), 429(33), 357(8), 339(4), } \\
327(5), 309(6), 298(10), 285(3)\end{array}$ & Luteolin 2"-O-pentosyl-6-C-hexoside & $1.48 \pm 0.01$ & $\begin{array}{l}\text { Luteolin-6-C- } \\
\text { glucoside }\end{array}$ & $370 \mathrm{~nm}$ \\
\hline 7 & 15.8 & 350 & 447 & $\begin{array}{l}429(22), 357(91), 327(92), 297(21), \\
285(11)\end{array}$ & Luteolin-6-C-glucoside & $3.37 \pm 0.01$ & $\begin{array}{l}\text { Luteolin-6-C- } \\
\text { glucoside }\end{array}$ & $370 \mathrm{~nm}$ \\
\hline 8 & 17.0 & 340 & 593 & $413(100), 341(10), 311(26)$ & Apigenin-6-C-hexoside-7-O-hexoside & $1.86 \pm 0.02$ & $\begin{array}{l}\text { Apigenin-6-C- } \\
\text { glucoside }\end{array}$ & $370 \mathrm{~nm}$ \\
\hline 9 & 17.7 & 338 & 563 & $\begin{array}{l}\text { 443(5), 413(43), 341(5), 311(3), } \\
293(28)\end{array}$ & Apigenin 2"-O-pentosyl-6-C-hexoside & $11.55 \pm 0.07$ & $\begin{array}{l}\text { Apigenin-6-C- } \\
\text { glucoside }\end{array}$ & $370 \mathrm{~nm}$ \\
\hline 10 & 18.1 & 340 & 563 & $\begin{array}{l}443(8), 413(46), 341(5), 311(8), \\
293(37)\end{array}$ & Apigenin 2"-O-pentosyl-6-C-hexoside & $0.61 \pm 0.02$ & $\begin{array}{l}\text { Apigenin-6-C- } \\
\text { glucoside }\end{array}$ & $370 \mathrm{~nm}$ \\
\hline 11 & 18.7 & 338 & 563 & $\begin{array}{l}\text { 443(11), 413(30), 341(5), 311(20), } \\
293(31)\end{array}$ & Apigenin 2"-O-pentosyl-6-C-hexoside & $1.33 \pm 0.05$ & $\begin{array}{l}\text { Apigenin-6-C- } \\
\text { glucoside }\end{array}$ & $370 \mathrm{~nm}$ \\
\hline 12 & 19.0 & 340 & 593 & $\begin{array}{l}473(3), 443(39), 371(6), 353(4), 341(3), \\
323(27)\end{array}$ & $\begin{array}{l}\text { Metluteolin } \\
2^{\prime \prime}-O \text {-pentosyl-6-C-hexoside }\end{array}$ & $0.63 \pm 0.02$ & $\begin{array}{l}\text { Luteolin-6-C- } \\
\text { glucoside }\end{array}$ & $370 \mathrm{~nm}$ \\
\hline 13 & 19.5 & 340 & 431 & 413(10), 341(58), 311(97) & Apigenin-6-C-glucoside & $5.56 \pm 0.07$ & $\begin{array}{l}\text { Apigenin-6-C- } \\
\text { glucoside }\end{array}$ & $370 \mathrm{~nm}$ \\
\hline 14 & 20.4 & 350 & 447 & $285(100)$ & Luteolin-7-O-glucoside & $1.43 \pm 0.01$ & $\begin{array}{l}\text { Luteolin-7-O- } \\
\text { glucoside }\end{array}$ & $370 \mathrm{~nm}$ \\
\hline 15 & 22.0 & 330 & 515 & $\begin{array}{l}353(89), 191(100), 179(76), 173(3), \\
161(4), 135(18)\end{array}$ & 3,5-O-Dicaffeoylquinic acid & $3.16 \pm 0.05$ & Chlorogenic acid & $280 \mathrm{~nm}$ \\
\hline \multirow[t]{4}{*}{16} & 24.7 & 328 & 515 & $\begin{array}{l}353(100), 191(14), 179(51), 173(100), \\
161(6), 135(12)\end{array}$ & 4,5-O-Dicaffeoylquinic acid & $1.51 \pm 0.05$ & Chlorogenic acid & $280 \mathrm{~nm}$ \\
\hline & & & & & Total phenolic acids & $14.01 \pm 0.06$ & & \\
\hline & & & & & Total flavonoids & $28.08 \pm 0.17$ & & \\
\hline & & & & & Total phenolic compounds & $42.09 \pm 0.11$ & & \\
\hline
\end{tabular}


(TBARS); malondialdehyde-thiobarbituric acid (MDA-TBA) abduct color intensity was measured by its absorbance at $532 \mathrm{~nm}$ and the inhibition ratio (\%) calculated using the following formula: $[(A-B) / A] \times 100 \%$, where $A$ and $B$ were the absorbance of the control and the sample solution, respectively. The results were expressed in $\mathrm{EC}_{50}$ values $(\mu \mathrm{g} / \mathrm{mL})$, i.e. the sample concentration that provides $50 \%$ of antioxidant activity or 0.5 of absorbance in the reducing power.

\subsection{Statistical analysis}

For each plant species, three samples were analyzed and all the assays were carried out in triplicate and the results were analyzed using a Student's $t$-test to determine the significant difference among two different samples, with $\alpha=0.05$. This analysis was carried out using SPSS v. 22.0 program.

\section{Results and discussion}

\subsection{Identification and quantification of phenolic compounds}

Data of the retention time, $\lambda_{\max }$ in the visible region, molecular ion, main fragment ions in $\mathrm{MS}^{2}$, tentative identification and concentration of phenolic acids and flavonoids in anise and coriander are presented in Tables 1 and 2, respectively. Fig. 1 shows the phenolic profiles of both samples recorded at $370 \mathrm{~nm}$.

Anise phenolic profile presented six hydroxycinnamic acid derivatives and ten flavone derivatives. 5-O-Caffeoylquinic acid (chlorogenic acid, compound 4), luteolin-6-C-glucoside (compound 7 ), apigenin 6-C-glucoside (compound 13), and luteolin-7-Oglucoside (compound 14) were positively identified according to their retention times, mass and UV-vis characteristics by comparison with commercial standards.

Compound $1\left([\mathrm{M}-\mathrm{H}]^{-}\right.$at $\mathrm{m} / z$ 353) was identified as 3-Ocaffeoylquinic (neo-chlorogenic acid) based on its $\mathrm{MS}^{2}$ fragmentation, yielding the base peak at $m / z 191$ and an intense ion at $\mathrm{m} / \mathrm{z} 179$, which is considered characteristic of 3-acylchlorogenic acids, as reported by Clifford et al. (2003). Compound 3 was easily distinguished from the other two caffeoyl-quinic acids by its base peak at $m / z 173$ [quinic acid- $\left.\mathrm{H}_{-} \mathrm{H}_{2} \mathrm{O}\right]^{-}$, accompanied by a secondary fragment ion at $\mathrm{m} / \mathrm{z} 179$ with approximately $86 \%$ abundance of base peak, which allowed identifying it as 4-O-caffeoylquinic acid (crypto-chlorogenic acid) according to the fragmentation pattern described by Clifford et al. (2003). Compounds 15 and 16 ([M-H $]^{-}$at $\mathrm{m} / \mathrm{z} 515$ ), corresponding to dicaffeoylquinic acids, were tentatively identified based on their elution order and fragmentation pattern and relative fragment ion abundances following the keys described by Clifford et al. (2003) and Clifford et al. (2005). In particular, compound 15 showed an intense signal for the fragment at $\mathrm{m} / \mathrm{z} 191$ [quinic acid-H] ${ }^{-}$, whereas the ion at $m / z 173$ was barely detectable. The opposite happened for compound 16 , where the ion at $m / z$

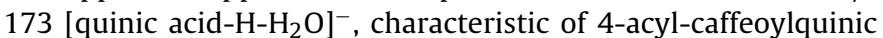
acids, appeared as the most important one, whilst that at $m / z 191$ was minor. Those features would allow assigning them as 3,5-Odicaffeoylquinic acid and 4,5-O-dicaffeoylquinic acid, respectively.

Compound $2\left([\mathrm{M}-\mathrm{H}]^{-}\right.$at $\left.m / z 409\right)$ was assigned as a $p$-coumaric acid derivative based on the characteristic fragment ions at $\mathrm{m} / \mathrm{z}$

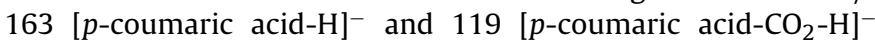
(Narváez-Cuenca et al., 2012) which was supported by the UV spectrum showing maximum wavelength at $310 \mathrm{~nm}$. Nevertheless, no definite structure could be matched to the molecular ion of the compound that remains just named as a $p$-coumaric acid derivative. The presence of chlorogenic acids, i.e., mono- and dicaffeoylquinic acids, in Pimpinella anisum has already been reported (Marques and Farah, 2009), as well as that of coumaric acids (Zielinski et al., 2014).

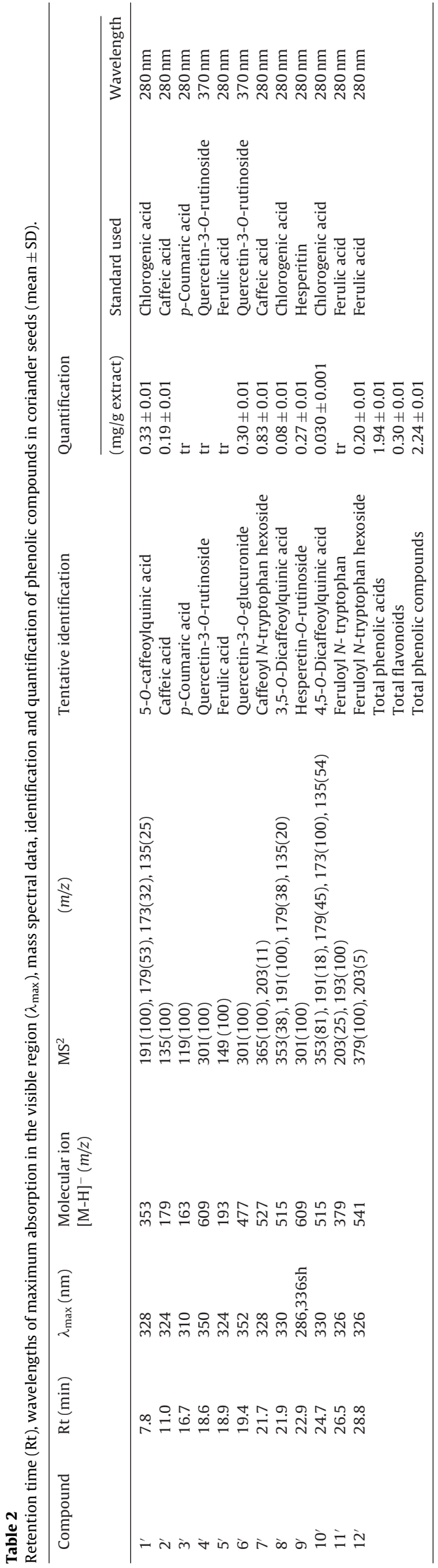



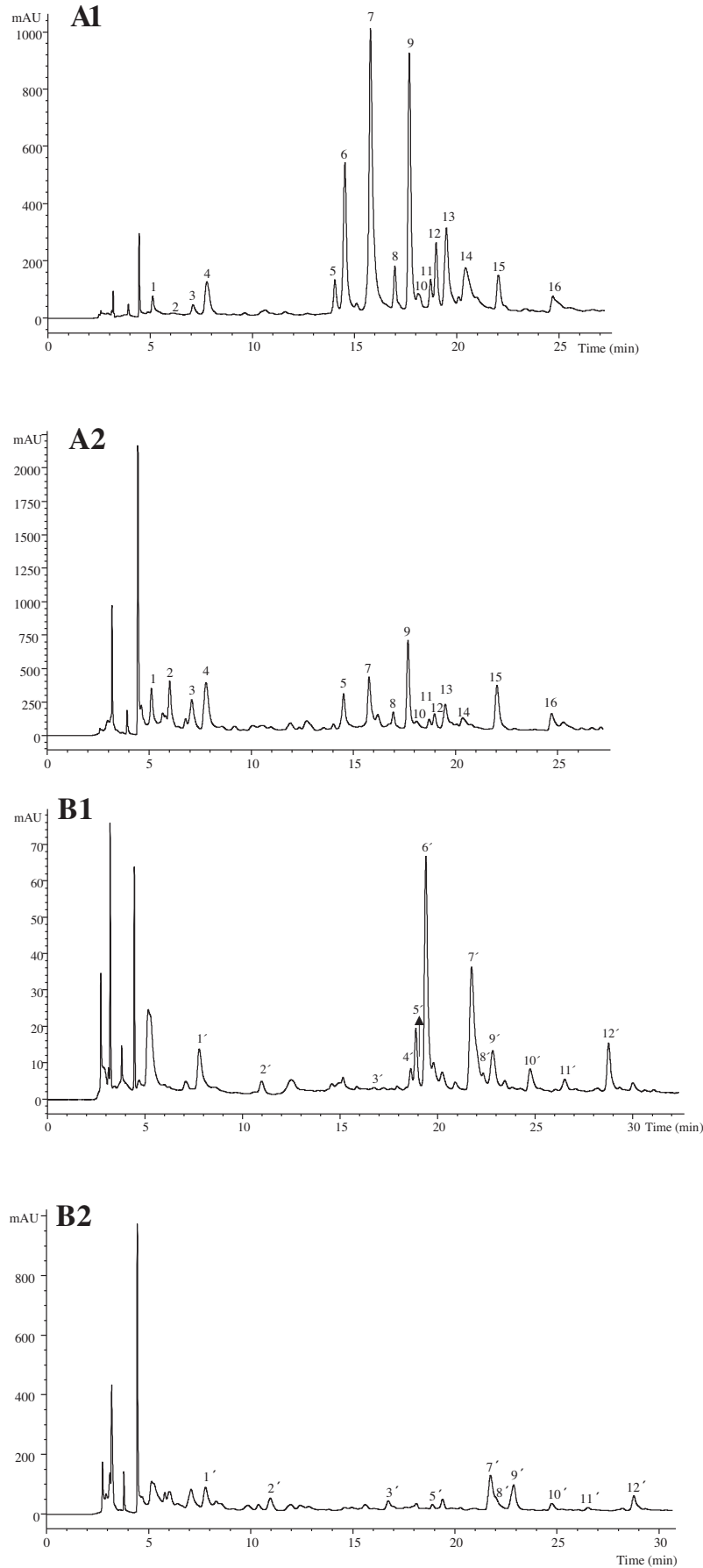

Fig. 1. Phenolic profile of anise (A) and coriander (B), where A1 and B1 were recorded at $370 \mathrm{~nm} ; \mathrm{A} 2$ and $B 2$ were recorded at $280 \mathrm{~nm}$ (numbering of the chromatograms are according to Tables 1 and 2 ).

The remaining compounds corresponded to $C$ - and $O, C$ glycosylated flavones and were identified according to the fragmentation patterns described by Ferreres et al., 2007, 2008, 2011. The fragmentation pattern majority compound $9\left([\mathrm{M}-\mathrm{H}]^{-}\right.$at $\mathrm{m} / \mathrm{z} 563$ ) was coherent with an $O, C$-diglycoside of apigenin. The loss of -120 mu leading to the ion at $m / 443$ supported the presence of a $C$-attached hexose, while the absence of an ion [(M-H)-90 $]^{-}$ pointed to a $6-C$ attachment. The lack of an ion $[(\mathrm{M}-\mathrm{H})-132]^{-}$from the loss of the pentosyl residue suggested that this sugar was not linked to the aglycone but to the other sugar; this was confirmed by the presence of an abundant $[(\mathrm{M}-\mathrm{H})-150]^{-}$ion at $m / z$ 413, which according to Ferreres et al. (2007) would be character-
Table 3

Antioxidant activity of the hydromethanolic extracts prepared from anise and coriander seeds (mean $\pm \mathrm{SD}$ ).

\begin{tabular}{lcclc}
\hline & Anise & Coriander & $\begin{array}{l}t \text {-Students test } \\
p \text {-value }\end{array}$ & Trolox \\
\hline $\begin{array}{l}\text { Antioxidant activity }\left(\mathrm{EC}_{50}, \mu \mathrm{g} / \mathrm{mL}\right) \\
\begin{array}{l}\text { DPPH scavenging } \\
\text { activity }\end{array}\end{array}$ & $687 \pm 28$ & $1930 \pm 24$ & $<0.001$ & $42 \pm 1$ \\
$\begin{array}{l}\text { Reducing power } \\
\begin{array}{l}\text { B-Carotene bleaching } \\
\text { inhibition }\end{array}\end{array}$ & $464 \pm 7$ & $2069 \pm 55$ & $<0.001$ & $41 \pm 1$ \\
TBARS inhibition & $132 \pm 2$ & $802 \pm 95$ & $<0.001$ & $18 \pm 1$ \\
\hline
\end{tabular}

The antioxidant activity was expressed as $\mathrm{EC}_{50}$ values (mean $\pm \mathrm{SD}$ ), what means that higher values correspond to lower reducing power or antioxidant potential. $\mathrm{EC}_{50}$ : extract concentration corresponding to $50 \%$ of antioxidant activity or 0.5 of absorbance in reducing power assay.

istic of an $O$-attached pentose on the $C$-glycosylating hexose. The $O$-glycosylation should not take place in the positions $6^{\prime \prime} 4^{\prime \prime}$ or $3^{\prime \prime}$ of the hexose, otherwise the fragment $[(\mathrm{M}-\mathrm{H})-120]^{-}$would not be produced. Finally, the ion at $m / z 293$ would result from the fragment at $m / z 413$ by further loss of a fragment of $120 \mathrm{mu}$ (partial loss of the $C$-attached hexose). All in all, this compound was tentatively identified as apigenin $2^{\prime \prime}-O$-pentosyl-6-C-hexoside. Compounds 10 and 11 showed the same pseudomolecular ion, $\mathrm{MS}^{2}$ fragmentation and UV spectra as compound 9, thus being also tentatively identified as apigenin 2 "- $O$-pentosyl-6-C-hexoside. The fact that these three compounds showed the same characteristics could be explained by the existence of different sugar moieties. Compounds $5\left([\mathrm{M}-\mathrm{H}]^{-}\right.$at $m / z 609), 6\left([\mathrm{M}-\mathrm{H}]^{-}\right.$at $\left.m / z 579\right)$ and $12\left([\mathrm{M}-\mathrm{H}]^{-}\right.$at $\left.m / z 593\right)$ presented the same fragmentation behaviour as peak 9 , so that the same reasoning was applied for their identification as luteolin $2^{\prime \prime}$ $O$-hexosyl-6-C-hexoside, luteolin $2^{\prime \prime}-O$-pentosyl-6- $C$-hexoside and methyl-luteolin 2"-O-pentosyl-6-C-hexoside, respectively. Finally, compound 8 presented a pseudomolecular ion $[\mathrm{M}-\mathrm{H}]^{-}$at $m / z 593$ that released three $\mathrm{MS}^{2}$ fragment ions at $m / z 431\left([\mathrm{M}-162]^{-}\right)$from

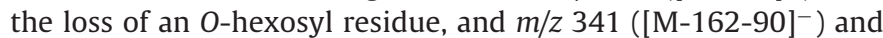
$311\left([\mathrm{M}-162-120]^{-}\right)$from the further loss of a $C$-attached hexose. It was thus identified as apigenin-6-C-hexoside-7-O-hexoside. As far as we know, none of these flavone derivatives have been previously described in anise, although Zielinski et al. (2014) reported the presence of other flavonoids such as flavan-3-ols and flavonols.

The phenolic profile of coriander seeds was mostly based on hydroxycinnamic acid derivatives some of them conjugated with amino acids (compounds $7^{\prime}, 11^{\prime}$ and $12^{\prime}$ ). All of them were already described in coriander seeds previously analysed by our group (Barros et al., 2012), with the exception of compound $8^{\prime}$, identified as 3,5-O-dicaffeoylquinic acid based on the same criteria as for compound 15 in anise. Furthermore, compounds $4^{\prime}$ and $6^{\prime}$ were identified as quercetin-3-O-rutinoside and quercetin-3-Oglucuronide, respectively, according to their retention time, UV and mass characteristics by comparison with authentic standards. Those compounds were not detected in coriander seeds in the previous study, although they were present in relevant levels in the vegetative parts (Barros et al., 2012). Compound $15^{\prime}\left([\mathrm{M}-\mathrm{H}]^{-}\right.$at $m / z$ 609) was tentatively assigned as hesperetin-O-rutinoside based on its UV and mass spectra. To the best of our knowledge such a compound has not been described in coriander. Caffeoyl $N$-tryptophan hexoside was the most abundant compound in coriander seeds, as also found by Barros et al. (2012).

\subsection{Evaluation of the antioxidant activity}

Table 3 shows the results of the antioxidant activity evaluation of anise and coriander extracts. Anise evidenced the highest antioxidant activity in all the assayed methods, although less pronounced than trolox. Similar properties were previous reported by Al-Ismail 
and Aburjai (2004), that evaluated the antioxidant activity of water and alcohol extracts of anise seeds and positively correlated it with the higher abundance in phenolic compounds (expressed as total phenols). In a similar manner, Christova-Bagdassarian et al. (2013) evaluating the antioxidant potential of five different plant extracts belonging to the Apiaceae family, among them anise and coriander seeds, concluded that the most prominent bioactive potential was observed in the plant extract with the highest abundance in phenolics and flavonoids. Anise presented the highest free radical scavenging activity, directly related with its higher content in phenolics ( $46.17 \mathrm{mg} \mathrm{GAE} / 100 \mathrm{~g} \mathrm{dw}$ ) and flavonoids $(17.43 \mathrm{mg}$ $\mathrm{CE} / 100 \mathrm{~g} \mathrm{dw})$, in comparison with coriander: phenolics $(17.04 \mathrm{mg}$ $\mathrm{GAE} / 100 \mathrm{gdw}$ ) and flavonoids (11.10 mg GAE/100g dw). Gülçın et al. (2003), also described a higher activity for anise ethanolic and water extracts than to the positive control used ( $\alpha$-tocopherol). Overall, in the present study, a positive correlation was also observed between phenolic constituents (mainly phenolic acids and flavone derivatives) and the antioxidant potential. Coriander extract, that showed the lowest antioxidant activity, also revealed the lowest phenolic compounds concentration, namely phenolic acids $(1.94 \pm 0.01 \mathrm{mg} / \mathrm{g}$ extract) and flavonoids $(0.30 \pm 0.01 \mathrm{mg} / \mathrm{g}$ extract).

\section{Conclusions}

Despite belonging both plants to the same genera, there were differences in their chemical composition and antioxidant activity, emphasising the wide variety and heterogeneity in the active principles of plants from the same botanical family. Indeed, these Apiaceae plants are traditionally recommended for different medicinal purposes. Nevertheless, further studies are necessary to check the in vivo efficacy of the studied plant extracts, as also to deepen knowledge on the modes of action. It is also important to note that culture conditions, climatic changes, harvesting time, storage and manipulation procedures, among others, should significantly affect the composition in phytochemicals and, consequently, the biological potential. Among them, phenolic compounds act as important contributors to the antioxidant potential of natural matrices, being this clearly evidenced in the present study: anise extract provided the most prominent antioxidant effect mainly conferred by its higher abundance in phenolic compounds. So, as both plants are commonly used as food complements, mainly through infusions and condiments, their characterization could provide considerable benefits to individuals, mainly through inciting their use as healthy promoters.

\section{Acknowledgements}

The authors are grateful to Foundation for Science and Technology (FCT, Portugal) for N. Martins grant (SFRH/BD/87658/2012), L. Barros researcher contract under "Programa Compromisso com Ciência - 2008" and financial support to the research centre CIMO (strategic project PEst-OE/AGR/UI0690/2011). The authors thank Soria Natural (Soria-Spain), for the supplying of the plant species.

\section{References}

Al-Ismail, K.M., Aburjai, T., 2004. Antioxidant activity of water and alcohol extracts of chamomile flowers, anise seeds and dill seeds. J. Sci. Food Agric. 84, 173-178

Albayrak, S., Aksoy, A., Sagdic, O., Albayrak, S., 2012. Antioxidant and antimicrobia activities of different extracts of some medicinal herbs consumed as tea and spices in Turkey. J. Food Biochem. 36, 547-554.

Albertpuleo, M., 1980. Fennel and anise as estrogenic agents. J. Ethnopharmacol. 2 337-344.

Andarwulan, N., Shetty, K., 1999. Phenolic content in differentiated tissue cultures of untransformed and Agrobacterium-transformed roots of anise (Pimpinella anisum L.). J. Agric. Food Chem. 47, 1776-1780.
Andarwulan, N., Shetty, K., 2000. Stimulation of novel phenolic metabolite, epoxy-pseudoisoeugenol-(2-methylbutyrate) (EPB), in transformed anise (Pimpinella anisum L.) root cultures by fish protein hydrolysates. Food Biotechnol. 14, 1-20.

Barros, L., Dueñas, M., Dias, M.I., Sousa, M.J., Santos-Buelga, C., Ferreira, I.C.F.R., 2012. Phenolic profiles of in vivo and in vitro grown Coriandrum sativum L. Food Chem. 132, 841-848.

Boskabady, M.H., Ramazani-Assari, M., 2001. Relaxant effect of Pimpinella anisum on isolated guinea pig tracheal chains and its possible mechanism(s). J. Ethnopharmacol. 74, 83-88.

Christova-Bagdassarian, V.L., Bagdassarian, K.S., Atanassova, M.S., 2013. Phenolic profile: antioxidant and antibacterial activities from the Apiaceae family (dry seeds). Mintage J. Pharm. Med. Sci. 2, 26-31.

Clifford, M.N., Johnston, K.L., Knight, S., Kuhnert, N., 2003. Hierarchical scheme for LC-MSn identification of chlorogenic acids. J. Agric. Food Chem. 51, 2900-2911.

Clifford, M.N., Johnston, K.L., Knight, S., Kuhnert, N.A., 2005. Discriminating between the six isomers of dicaffeoylquinic acid by LC-MSn. J. Agric. Food Chem. 53, 3821-3832.

Dawidar, A.M., Mogib, M.A., El-Ghorab, A.H., Mahfouz, M., Elsaid, F.G., Hussien, K. 2008. Chemical composition and effect of photo-oxygenation on biological activities of Egyptian commercial anise and fennel essential oils. J. Essent. Oil Bear. Plants 11, 124-136.

Dhanapakiam, P., Joseph, J.M., Ramaswamy, V.K., Moorthi, M., Kumar, A.S., 2008. The cholesterol lowering property of coriander seeds (Coriandrum sativum): mechanism of action. J. Environ. Biol. 29, 53-56.

Dias, M.I., Barros, L., Sousa, M.J., Ferreira, I.C.F.R., 2011. Comparative study of lipophilic and hydrophilic antioxidants from in vivo and in vitro grown Coriandrum sativum. Plant foods Hum. Nutr. 66, 181-186.

Ergin, V., Hariry, R.E., Karasu, C., 2013. Carbonyl stress in aging process: role of vitamins and phytochemicals as redox regulators. Aging Dis. 4, 276-294.

Fernandez-Panchon, M.S., Villano, D., Troncoso, A.M., Garcia-Parrilla, M.C., 2008. Antioxidant activity of phenolic compounds: from in vitro results to in vivo evidence. Crit. Rev. Food Sci. Nutr. 48, 649-671.

Ferreres, F., Andrade, P.B., Valentao, P., Gil-Izquierdo, A., 2008. Further knowledge on barley (Hordeum vulgare L.) leaves O-glycosyl-C-glycosyl flavones by liquid chromatography-UV diode-array detection-electrospray ionisation mass spectrometry. J. Chromatogr. A 1182, 56-64.

Ferreres, F., Gil-Izquierdo, A., Andrade, P.B., Valentao, P., Tomás-Barberán, F.A., 2007. Characterization of C-glycosyl flavones O-glycosylated by liquid chromatography-tandem mass spectrometry. J. Chromatogr. A 1161, 214-223.

Ferreres, F., Gil-Izquierdo, A., Vinholes, J., Grosso, C., Valentão, P., Andrade, P.B., 2011. Approach to the study of C-glycosyl flavones acylated with aliphatic and aromatic acids form Spergularia rubra by high-performance liquid chromatography-photodiode array detection/electrospray ionization multi-stage mass spectrometry. Rapid Commun. Mass Spectrom. RCM 25 $700-712$.

Gülçın, İ., Oktay, M., Kıreçcı, E., Küfrevıoğlu, Ö., 2003. Screening of antioxidant and antimicrobial activities of anise (Pimpinella anisum L.) seed extracts. Food Chem. 83, 371-382.

Halberstein, R.A., 2005. Medicinal plants: historical and cross-cultural usage patterns. Ann. Epidemiol. 15, 686-699.

Jachak, S.M., Saklani, A., 2007. Challenges and opportunities in drug discovery from plants. Curr. Sci. 92, 1251-1257.

Kačániová, M., Vukovič, N., Horská, E., Salamon, I., Bobková, A., Hleba, L., Fiskelová, M., Vatl'ák, A., Petrová, J., Bobko, M., 2014. Antibacterial activity against Clostridium genus and antiradical activity of the essential oils from different origin. J. Environ. Sci. Health. B 49, 505-512.

Kiralan, M., Bayrak, A., Abdulaziz, O.F., Özbucak, T., 2012. Essential oil composition and antiradical activity of the oil of Iraq plants. Nat. Prod. Res. 26, 132-139.

Kunzemann, J., Herrmann, K., 1977. Isolation and identification of flavon(ol)-O-glycosides in caraway (Carum carvi L.), fennel (Foeniculum vulgare Mill.), anise (Pimpinella anisum L.), and coriander (Coriandrum sativum L.), and of flavon-C-glycosides in anise. Zeitschrift Leb. Untersuchung Und-forsch. 164, 194-200.

Li, A., Li, S., Zhang, Y., Xu, X., Chen, Y., Li, H., 2014. Resources and biological activities of natural polyphenols. Nutrients 6, 6020-6047.

Marques, V., Farah, A., 2009. Chlorogenic acids and related compounds in medicinal plants and infusions. Food Chem. 113, 1370-1376.

Martins, N., Barros, L., Dueñas, M., Santos-Buelga, C., Ferreira, I.C.F.R., 2015. Characterization of phenolic compounds and antioxidant properties of Glycyrrhiza glabra L. rhizomes and roots. RSC Adv. 5, 26991-26997.

de Almeida Melo, E., Bion, F.M., Filho, J.M., Guerra, N.B., 2003. In vivo antioxidant effect of aqueous and etheric coriander (Coriandrum sativum L.) extracts. Eur. J. Lipid Sci. Technol. 105, 483-487.

de Almeida Melo, E., Filho, J.M., Guerra, N.B., 2005. Characterization of antioxidant compounds in aqueous coriander extract (Coriandrum sativum L.). LWT-Food Sci. Technol. 38, 15-19.

Msaada, K., Jemia, M., Ben, S., alem, N., Bachrouch, O., Sriti, J., Tammar, S., Bettaieb, I., Jabri, I., Kefi, S., Limam, F., Marzouk, B., 2013. Antioxidant activity of methanolic extracts from three coriander (Coriandrum sativum L.) fruit varieties. Arab. J. Chem., http://dx.doi.org/10.1016/j.arabjc.2013.12.011 (In Press).

Nadeem, M., Anjum, F.M., Khan, M.I., Tehseen, S., El-Ghorab, A., Sultan, J.I., 2013. Nutritional and medicinal aspects of coriander (Coriandrum sativum L.): a review. Br. Food J. 115, 743-755. 
Narváez-Cuenca, C.E., Vincken, J.P., Gruppen, H., 2012. Identification and quantification of (dihydro) hydroxycinnamic acids and their conjugates in potato by UHPLC-DAD-ESI-MS. Food Chem. 130, 730-738.

Nasri, H., Baradaran, A., Shirzad, H., Rafieian-kopaei, M., 2014. New concepts in nutraceuticals as alternative for pharmaceuticals. Int. J. Prev. Med. 5, 1487-1499.

Neffati, M., Sriti, J., Hamdaoui, G., Kchouk, M.E., Marzouk, B., 2011. Salinity impact on fruit yield, essential oil composition and antioxidant activities of Coriandrum sativum fruit extracts. Food Chem. 124, 221-225.

Pathak, N.L., Kasture, S.B., Bhatt, N.M., Rathod, J.D., 2011. Phytopharmacological properties of Coriander sativum as a potential medicinal tree: an overview. J. Appl. Pharm. Sci. 1, 20-25.

Petrovska, B.B., 2012. Historical review of medicinal plants' usage. Pharmacogn. Rev. 6, 1-5.

Prakash, B., Singh, P., Kedia, A., Dubey, N.K., 2012. Assessment of some essential oils as food preservatives based on antifungal, antiaflatoxin, antioxidant activities and in vivo efficacy in food system. Food Res. Int. 49, 201-208.

Ramkissoon, J.S., Mahomoodally, M.F., Ahmed, N., Subratty, A.H., 2013. Antioxidant and anti-glycation activities correlates with phenolic composition of tropical medicinal herbs. Asian Pac. J. Trop. Med. 6, 561-569.

Rubió, L., Motilva, M.-J., Romero, M.-P., 2013. Recent advances in biologically active compounds in herbs and spices: a review of the most effective antioxidant and anti-inflammatory active principles. Crit. Rev. Food Sci. Nutr. 53, 943-953.
Shojaii, A., Fard, M.A., 2012. Review of pharmacological properties and chemical constituents of Pimpinella anisum. Int. Sch. Res. Netw.-ISRN Pharm. 2012, 1-8.

Sreelatha, S., Inbavalli, R., 2012. Antioxidant, antihyperglycemic, and antihyperlipidemic effects of Coriandrum sativum leaf and stem in alloxan-induced diabetic rats. J. Food Sci. 77, 119-123.

Sulaiman, S.F., Sajak, A.A.B., Ooi, K.L., Seow, E.M., 2011. Effect of solvents in extracting polyphenols and antioxidants of selected raw vegetables. J. Food Compos. Anal. 24, 506-515.

Tang, E.L.H., Rajarajeswaran, J., Fung, S.Y., Kanthimathi, M.S., 2013. Antioxidant activity of Coriandrum sativum and protection against DNA damage and cancer cell migration. BMC Complement Altern. Med. 13, 347.

Topal, U., Sasaki, M., Goto, M., Otles, S., 2008. Chemical compositions and antioxidant properties of essential oils from nine species of Turkish plants obtained by supercritical carbon dioxide extraction and steam distillation. Int. J. Food Sci. Nutr. 59, 619-634.

Wangensteen, H., Samuelsen, A.B., Malterud, K.E., 2004. Antioxidant activity in extracts from coriander. Food Chem. 88, 293-297.

Zielinski, A.A.F., Haminiuk, C.W.I., Alberti, A., Nogueira, A., Demiate, I.M., Granato, D., 2014. A comparative study of the phenolic compounds and the in vitro antioxidant activity of different Brazilian teas using multivariate statistical techniques. Food Res. Int. 60, 246-254. 